\title{
Are the streams of the Sinos River basin of good water quality? Aquatic macroinvertebrates may answer the question
}

\author{
Bieger, L., Carvalho, ABP., Strieder, MN., Maltchik, L.* and Stenert, C. \\ Ecology and Conservation of Aquatic Ecosystems, Universidade do Vale do Rio dos Sinos - UNISINOS, \\ CEP 93022-000, São Leopoldo, Rio Grande do Sul, Brazil \\ *e-mail: maltchik@unisinos.br \\ Received February 21, 2010 - Accepted April 29, 2010 - Distributed December 31, 2010
}

(With 1 figure)

\begin{abstract}
Macroinvertebrate communities are one of the most used groups in assessments of water quality, since they respond directly to the level of contamination of aquatic ecosystems. The main objective of this study was the assessment of the water quality of the Sinos River basin (Rio Grande do Sul state, Brazil) through biotic indices based on the macroinvertebrate community ("Family Biotic Index - FBI", and "Biological Monitoring Working Party Score System - BMWP"). Three lower order streams ( $2^{\text {nd }}$ order) were selected in each one of three main regions of the basin. In each stream, the samplings were performed in three reaches (upper, middle, and lower), totalling 27 reaches. Two samplings were carried in each reach over one year (winter and summer). A total of 6,847 macroinvertebrates distributed among 54 families were sampled. The streams from the upper region were of better water quality than the lower region. The water quality did not change between the upper, middle and lower reaches of the streams. However, the upper reaches of the streams were of better water quality in all the regions of the basin. The water quality of the streams did not vary between the summer and the winter. This result demonstrated that water quality may be analysed in both studied seasons (summer and winter) using biotic indices. The analysis of the results allows us to conclude that the biotic indices used reflected the changes related to the water quality along the longitudinal gradient of the basin. Thus, aquatic macroinvertebrates were important bioindicators of the water and environmental quality of the streams of the Sinos River basin.
\end{abstract}

Keywords: hydric resources, bioindicator, biomonitoring, water quality, biotic indices.

\section{Os arroios da bacia hidrográfica do Rio dos Sinos estão com boa qualidade da água? Os macroinvertebrados aquáticos podem responder a questão}

\section{Resumo}

A comunidade de macroinvertebrados aquáticos é um dos grupos mais utilizados na avaliação da qualidade da água, pois respondem de forma diferente ao grau de contaminação dos ecossistemas aquáticos. O principal objetivo deste estudo foi avaliar a qualidade da água na bacia hidrográfica do Rio dos Sinos (Rio Grande do Sul, Brasil) através de índices bióticos baseados em comunidades de macroinvertebrados aquáticos (Family Biotic Index - FBI, e Biological Monitoring Working Party Score System - BMWP). Três arroios de pequena ordem ( $2^{\circ}$ ordem) foram selecionados em cada uma das três principais regiões da bacia. Em cada arroio foram realizadas coletas em três trechos (superior, médio e inferior), totalizando 27 trechos. Foram realizadas duas coletas ao longo de um ano em cada trecho de arroio (inverno e verão). Um total de 6.847 macroinvertebrados distribuídos em 54 famílias foi coletado nos arroios. Os arroios da região superior da bacia apresentaram uma melhor qualidade da água do que os da região inferior. A qualidade da água não variou entre os trechos superior, médio e inferior dos arroios. Entretanto, os trechos superiores dos arroios apresentaram uma melhor qualidade da água em todas as regiões da bacia. A qualidade da água nos arroios não variou entre o verão e o inverno. Este resultado demonstrou que a qualidade da água pode ser analisada em ambas as estações do ano (verão e inverno), utilizando os índices bióticos. A análise dos resultados nos permite concluir que os índices bióticos utilizados refletiram as mudanças relacionadas à qualidade da água ao longo do gradiente longitudinal da bacia. Portanto, os macroinvertebrados aquáticos foram importantes bioindicadores da qualidade da água e da qualidade ambiental dos arroios da bacia hidrográfica do Rio dos Sinos.

Palavras-chave: recursos hídricos, bioindicador, biomonitoramento, qualidade da água, índices bióticos. 


\section{Introduction}

The environmental changes caused by urban and agricultural expansion have generated concern with the availability and quality of water resources (Callisto et al., 2001). The relationship between land occupation and the changes of the streams is complex and may be influenced by several factors under different spatial scales (Allan et al., 1997; Goldstein et al., 2007). On the basin scale, the main river and its tributaries are able to detect the environmental changes throughout the basin (Huntsaker and Levine, 1995; Moreno and Callisto, 2004). Changes in stream upper reaches influence the lower courses due to strong water and sediment exchange between the regions (Callisto et al., 2001).

The methods for assessing the water quality of the ecosystems are based on several physical, chemical and microbiological variables. Since the 1970's, researchers have been discussing that such methodologies are not sufficient to attend to the multiple uses of the water as they reflect the water quality only at the sampling time (Arias et al., 2007). Currently, it is consensual among researchers the need for a substantial amount of biological information for monitoring the water quality of aquatic ecosystems to identify its effects on the biological community as well (Metcalfe, 1989; Whitfield, 2001). Thus, aquatic biota has been used as an important tool for acquiring information regarding the integrity and environmental quality of freshwater ecosystems.

Biomonitoring is defined as the systematic use of biological responses to assess environmental changes, usually anthropogenic impacts (Matthews et al., 1982). Macroinvertebrate communities are one of the most used groups in the assessments of water quality, since they respond directly to the level of contamination of aquatic ecosystems (Resh, 2007). The relationships between macroinvertebrate structure and environmental factors (anthropogenic or natural) are affected by the change of the habitat quality. Such changes modify its population (Marques and Barbosa, 2001) through the loss of riparian vegetation, decrease in habitat heterogeneity, food availability, and changes in the physical and chemical water quality (Harding et al., 1998; Galdean et al., 2000; Kasangaki et al., 2008).

Macroinvertebrate communities may be used for water biomonitoring through the application of the biotic indices (Duran, 2006). These biotic indices are numeric expressions that combine a quantitative measure of the species diversity with the qualitative information regarding the ecological sensitivity of the individuals or taxa in relation to a certain level of pollution (Czerniawska-Kusza, 2005). Based on the Saprobic System of Kolkwitz and Marsson (1908), several biotic indices have been developed worldwide, for instance, the Biological Monitoring Working Party Score System - BMWP (Armitage et al., 1983) and the Family Biotic Index - FBI (Hilsenhoff, 1987). These two indices have been already tested and adapted in several countries. Biotic indices have been used in Brazil for assessing the water quality of surface water (including adaptations of the biotic indices), such the BMWP index, adapted for the Velhas River basin, Minas Gerais state, Brazil (Junqueira and Campos, 1998) and for the Meia Ponte River basin, Goias state, Brazil (Monteiro et al., 2008).

The Sinos River is one of the main rivers of Rio Grande do Sul. Due to the economic activities carried out in the basin, it is considered to be one of the most impacted rivers of the Guaíba Lake basin (Comitesinos, 2000). The municipalities of the basin have approximately 1.6 million inhabitants - representing $17 \%$ of the population of the state. The Sinos River basin represents $17.3 \%$ of the economy of Rio Grande do Sul, mainly in the shoe-leather, mechanical and petrochemical sectors. The water of the basin is used for agricultural, industrial and population supplies. On the other hand, these aquatic ecosystems are also used as a medium of dilution of domestic, industrial and rural waste. These multiple uses of the water threaten the sustainability of one of the main basins of southern Brazil.

Studies regarding macroinvertebrate communities in the water quality monitoring of the Sinos River basin are scarce (Strieder et al., 2003; 2006a,b), and most of them were carried out on small spatial scales (sub-basin or specific streams). The main objective of this study was the assessment of the water quality of the Sinos River basin (Rio Grande do Sul state, Brazil) through the biotic indices based on the macroinvertebrate community. The specific objectives of the study were: (1) to compare the water quality of the streams between different regions of Sinos River basin (upper, middle and lower); (2) to assess the water quality along the stream reaches (upper, middle and lower); (3) to assess whether the water quality of the streams varies between seasons; and (4) to analyse the relationship of the water quality with the main environmental impacts observed in the Sinos River basin. Assuming that the Sinos River basin presents different levels of degradation and human occupation along its longitudinal gradient, the following hypothesis could be tested: the streams from the upper region of the Sinos river basin have better water quality than that of the lower region.

\section{Material and Methods}

\subsection{Study area}

The Sinos River basin is located at the northeastern part of Rio Grande do Sul between the geographic coordinates latitude $29^{\circ} 20^{\prime} \mathrm{S}$ and $30^{\circ} 10^{\prime} \mathrm{S}$ and longitude $50^{\circ} 15^{\prime} \mathrm{W}$ and $51^{\circ} 20^{\prime} \mathrm{W}$, and it is inserted in the Guaíba Lake basin. The Sinos River is $190 \mathrm{~km}$ long, its source is at $900 \mathrm{~m}$ in the Serra Geral Upland and flows into the delta of Jacuí River, $5 \mathrm{~m}$ above sea level. The climate of the region is humid subtropical, and the annual precipitation of the Sinos River basin varies between 1,200 and 2,000 mm, being well-distributed throughout the seasons.

The basin presents an area of approximately $4,000 \mathrm{~km}^{2}$, which covers 32 municipalities, many of which are characterised by high population density and industrial activities, especially in the metropolitan area of Porto 
Alegre (DRH/SEMA, 2008). The plant coverage of the basin has been reduced to nearly $10 \%$ of its original area. In the upper region of the basin, shoe-leather industrial activities are predominant. In the middle and lower regions, other activities such as paper production, metallurgy, steeling, oil refinery, and mining are important (DRH/ SEMA, 2008).

\subsection{Data sampling}

To assess the water quality of the streams of the Sinos River basin, three lower order streams ( $2^{\text {nd }}$ order) were selected in each one of three main regions of the basin (Figure 1). In the upper region, the streams were the Sinos, Caraá and Carvalho. In the middle region, the selected streams were the Tucanos, Guarda and Funil. And in the lower region, the streams were Guari-Taimbé, Peão and Kruze. The geographic location of the sampling locations was determined using a Global Positioning System ("GPS"). In each stream, samplings were performed in three reaches (upper, middle, and lower), totalising 27 reaches. Two samplings were carried out in each reach over one year: 1) from July to September, 2007 (winter period); and 2) from March to April, 2008 (summer period), totalising 54 samples.

\subsection{Macroinvertebrate sampling}

The macroinvertebrates were sampled according to the protocol of the United StatesEnvironmental Protection Agency (USEPA). In each stream reach, the multihabitat approach was used, in which the macroinvertebrates are collected from all available stream habitats (margins, rocky, sandy, muddy, and litter bottom) by kicking the substrate with a kicknet (500- $\mu \mathrm{m}$ sieve) and jabbing with a dipnet

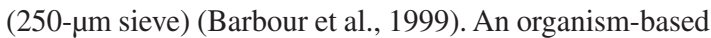
sub-sample with 100 individuals was sorted in the field and preserved using $70 \%$ ethanol. Macroinvertebrates were identified to families according to Merritt and Cummins (1996), Lopretto and Tell (1995), Fernández and Dominguez (2001), and Costa and Siminka (2006).

\subsection{Biotic indices}

The water quality of the streams of Sinos River basin was assessed using the family-level biotic index (FBI) (Hilsenhoff, 1987) and through the Biological Monitoring Working Party (BMWP) (Armitage et al., 1983). For this study, seven categories of water quality were considered (Table 1) for the FBI and the BMWP. The indices of general quality of the water of each studied stream were integrated with the sum of the three sampled reaches, per season.

\subsection{Environmental impacts of the Sinos River basin}

According to assessments carried out in 2006 by the Project entitled MONALISA - "Monitoramento Ambiental Local de Impactos Sobre Arroios da Bacia do Rio dos Sinos" (Local Environmental Monitoring of Impacts upon the Streams of Sinos River Basin), the studied streams presented different states of environmental degradation, assessed according to the Stream walk surveys methodology

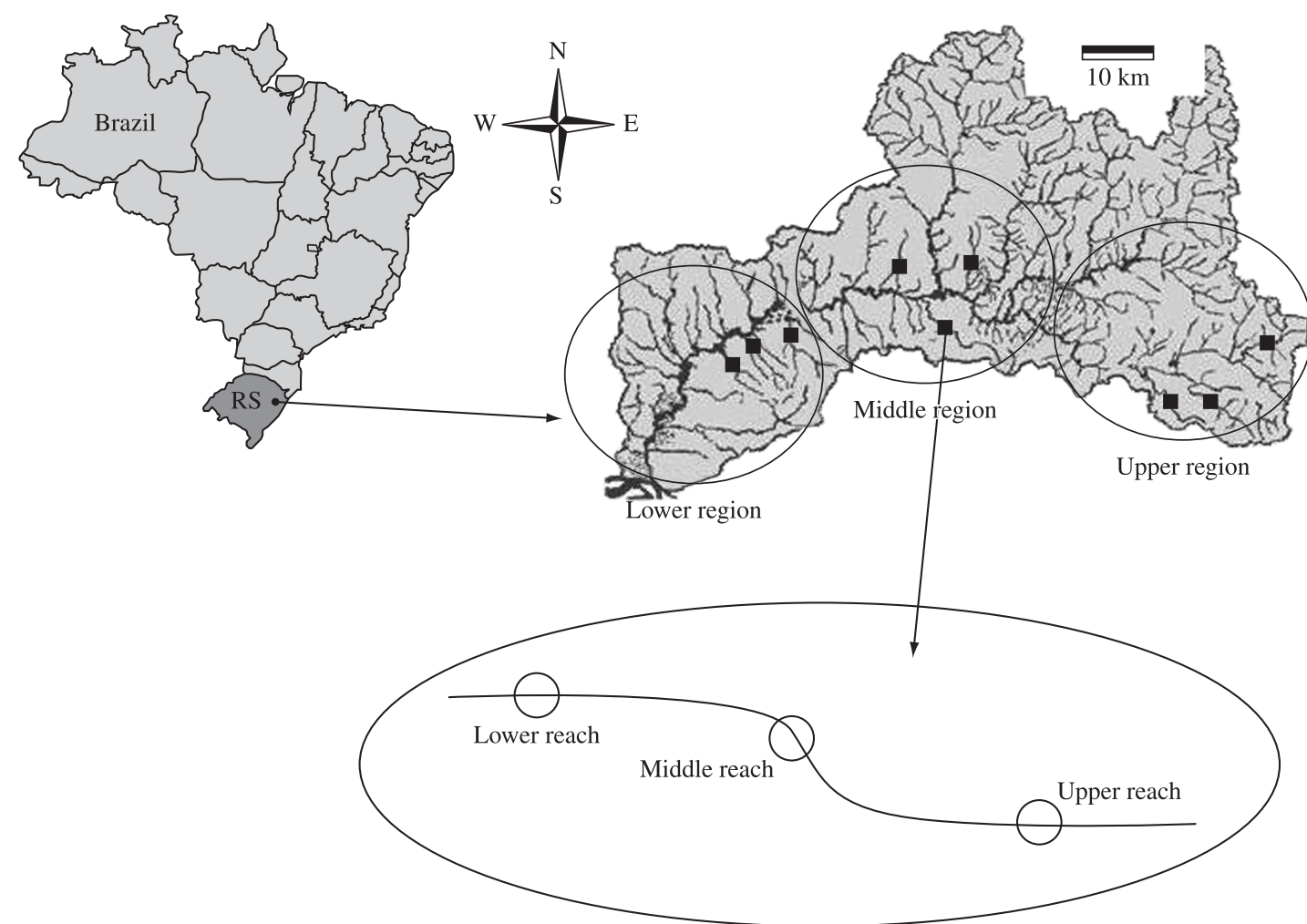

Figure 1. Stream reaches sampled in the three regions of the Sinos River basin, Rio Grande do Sul, Brazil. 
Table 1. Water quality based on biotic indices (FBI and BMWP).

\begin{tabular}{cccc}
\hline FBI & $\begin{array}{c}\text { Water } \\
\text { quality }\end{array}$ & BMWP & $\begin{array}{c}\text { Water } \\
\text { quality }\end{array}$ \\
\hline $0-3.75$ & $\begin{array}{c}\text { Class I - } \\
\text { Excellent }\end{array}$ & $\geq 90$ & $\begin{array}{c}\text { Class I - } \\
\text { Excellent }\end{array}$ \\
\hline $3.76-4.25$ & $\begin{array}{c}\text { Class II - } \\
\text { Very good }\end{array}$ & $75-89$ & $\begin{array}{c}\text { Class II - } \\
\text { Very good }\end{array}$ \\
\hline $4.26-5$ & $\begin{array}{c}\text { Class III - } \\
\text { Good }\end{array}$ & $60-74$ & $\begin{array}{c}\text { Class III - } \\
\text { Good }\end{array}$ \\
\hline $5.01-5.75$ & $\begin{array}{c}\text { Class IV - } \\
\text { Fair }\end{array}$ & $45-59$ & $\begin{array}{c}\text { Class IV - } \\
\text { Fair }\end{array}$ \\
\hline $5.76-6.50$ & $\begin{array}{c}\text { Class V - } \\
\text { Regular }\end{array}$ & $30-44$ & $\begin{array}{c}\text { Class V - } \\
\text { Regular }\end{array}$ \\
\hline $6.51-7.25$ & $\begin{array}{c}\text { Class VI - } \\
\text { Poor }\end{array}$ & $15-29$ & $\begin{array}{c}\text { Class VI - } \\
\text { Poor }\end{array}$ \\
\hline $7.26-10$ & $\begin{array}{c}\text { Class VII - } \\
\text { Very poor }\end{array}$ & $\leq 14$ & $\begin{array}{c}\text { Class VII - } \\
\text { Very poor }\end{array}$ \\
\hline
\end{tabular}

of the United States Environmental Protection Agency (USEPA). The streams were classified according to the severity of the environmental impacts (bed change, erosion, fish-migration barrier, waste outflow, riparian vegetation deforestation, garbage deposit, and water catchments). Based on these assessments, a total index of environmental quality (Monalisa index) of the studied stream was integrated, where each category of impact had its "impact factor" defined. The Monalisa Index (MI) was determined by the sum of the multiplication between the impact factor, severity, and number of times in which a certain environmental impact occurred (Comitesinos/ Unisinos, 2006). In this sense, the environmental quality of a stream decreases as the Monalisa Index increases.

\subsection{Data analysis}

Variations of the water quality between different regions of the Sinos River basin and the stream reaches were quantified using One-Way ANOVA, with post-hoc Tukey test. The variation of water quality between the summer and winter was quantified through the $t$-test. The correlation between the biotic indices (FBI and BMWP) and the Monalisa index was tested using Pearson's correlation. The analyses were performed using Systat 12 (Systat, 2007) after confirming that the data satisfied the statistical assumptions of these parametric tests.

\section{Results}

A total of 6,847 macroinvertebrates distributed among 54 families were sampled in the streams of the Sinos River basin. The families of macroinvertebrates belonged to three phyla (Arthropoda, Mollusca, and Anellida), and six classes (Table 2). The class that presented the highest number of families was Insecta (45), being mainly represented by the orders Hemiptera (nine families), Coleoptera (eight families), Diptera (seven families), and Odonata (seven families). Insecta represented the majority of the individuals sampled $(85.1 \%)$. Chironomidae was the most abundant macroinvertebrate family, corresponding to $23 \%$ of the total of the individuals sampled, followed by Baetidae, Gyrinidae, and Veliidae, with 7.4, 7.2, and 6.5\%, respectively (Table 2). Chironomidae was also the most frequent macroinvertebrate family, occurring in the 27 stream reaches, followed by the families Calopterygidae and Baetidae (both present in $81.5 \%$ of the stream reaches), Gyrinidae (77.8\%), Veliidae $(74.1 \%)$, Gerridae and Coenagrionidae (both present in $70.4 \%$ of the stream reaches) (Table 2).

The water quality varied between the upper, middle and lower regions of the Sinos River basin in the summer $\left(\mathrm{FBI}-\mathrm{F}_{2,6}=5.178, \mathrm{p}=0.049, \mathrm{BMWP}-\mathrm{F}_{2,6}=7.408\right.$, $\mathrm{p}=0.024)$. The streams from the upper region presented a better water quality than the lower region (FBI - Tukey, $\mathrm{p}=0.042$, BMWP - Tukey, $\mathrm{p}=0.026$ ). During the winter, the water quality did not changed between the regions (FBI and BMWP - p > 0.05). In the upper region, the water quality of the streams varied between classes I and III (from excellent to good) for the FBI, and excellent (class I) for the BMWP (Table 3). In the middle region of the basin, the water quality of the streams varied between classes III and V (from good to regular) for the FBI, and excellent (class I) for the BMWP (Table 3). In the lower region of the basin, the water quality of the streams varied between classes III and VI (from good to poor) for the FBI, and between classes I and IV (from excellent to fair) for the BMWP (Table 3).

The water quality did not change between the upper, middle and lower reaches of the streams in the summer $\left(\mathrm{FBI}-\mathrm{F}_{2,24}=0.975, \mathrm{p}=0.392, \mathrm{BMWP}-\mathrm{F}_{2,24}=0.555\right.$, $\mathrm{p}=0.581)$. In the winter, the water quality was also similar among the stream reaches $\left(\mathrm{FBI}, \mathrm{F}_{2,24}=1.235, \mathrm{p}=0.309\right.$, and BMWP, $\left.\mathrm{F}_{2,24}=0.036, \mathrm{p}=0.965\right)$. However, the upper reaches of the streams presented a better water quality in all the regions of the basin (Table 4). The water quality of the upper reaches of the streams varied between classes and I and IV (from excellent to fair) for the FBI and between I and IV (from excellent to fair) for the BMWP. In the middle reaches of the streams, the water quality varied between classes II and VII (from very good to very poor) for the FBI and between classes I and VII (from excellent to very poor) for the BMWP. In the lower reaches of the streams, the water quality varied between classes I and VII (from excellent to very poor) for the FBI and for the BMWP (Table 4).

The water quality of the streams did not vary between the summer and the winter $\left(\mathrm{FBI}, \mathrm{t}_{16}=-0.370, \mathrm{p}=0.716\right.$, and BMWP, $\left.\mathrm{t}_{16}=0.162, \mathrm{p}=0.874\right)$. The Monalisa index varied form zero to 33 along the Sinos River basin (Table 4). In the three regions of the basin, either the streams without great impact or those with compromised environmental quality were observed (Table 4). The Monalisa index also revealed that the upper reaches of the streams presented a better environmental quality (from zero to 10.5 ) than the middle (between seven and 30) and lower reaches (from six to 33) (Table 4). While the family-level biotic index (FBI) was positively correlated with the Monalisa index 
Table 2. Taxonomic list of macroinvertebrates observed in the streams of the Sinos River basin.

\begin{tabular}{|c|c|c|c|c|c|}
\hline & & Class & Order & Family & Stream Occurrence* \\
\hline \multirow{6}{*}{ 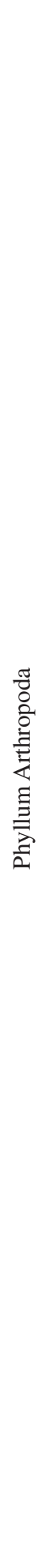 } & \multirow{6}{*}{ 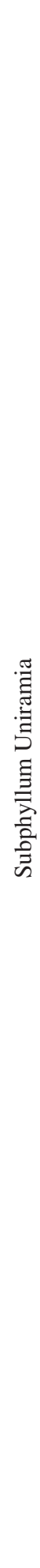 } & Insecta & Diptera & $\begin{array}{l}\text { Blephariceridae } \\
\text { Ceratopogonidae } \\
\text { Chironomidae } \\
\text { Corduliidae } \\
\text { Dixidae } \\
\text { Simuliidae } \\
\text { Tipulidae }\end{array}$ & $\begin{array}{l}\text { RS } \\
\text { RS } \\
\text { RS, CA, CV, AT, AG, AF, GT, AP, AK } \\
\text { CA } \\
\text { RS, CA } \\
\text { RA, CA, CV, AT, AG, AF, GT, AP, AK } \\
\text { RS, CA, CV, AG, AK }\end{array}$ \\
\hline & & & Hemiptera & $\begin{array}{l}\text { Belostomatidae } \\
\text { Corixidae } \\
\text { Gelastocoridae } \\
\text { Gerridae } \\
\text { Hydrometridae } \\
\text { Mesovellidae } \\
\text { Naucoridae } \\
\text { Nepidae } \\
\text { Vellidae }\end{array}$ & $\begin{array}{l}\text { CA, CV, AT, AG, AF, GT, AP, AK } \\
\text { RA, CA, CV, AT, AG, AF, GT } \\
\text { AG } \\
\text { RS, CA, CV, AT, AG, AF, GT, AP, AK } \\
\text { CA, CV } \\
\text { CV, AT, AG, GT } \\
\text { RS, CA, AG, GT } \\
\text { CA, AT, AG, AF, GT } \\
\text { RS, CA, CV, AT, AG, AF, GT, AP, AK }\end{array}$ \\
\hline & & & Ephemeroptera & $\begin{array}{l}\text { Dryopidae } \\
\text { Dytiscidae } \\
\text { Elmidae } \\
\text { Gyrinidae } \\
\text { Hydrophilidae } \\
\text { Noteridae } \\
\text { Psephenidae } \\
\text { Staphylinidae }\end{array}$ & $\begin{array}{l}\text { RS, CA, CV, AT, AG, AF, GT, AP, AK } \\
\text { CA, CV, AT, AF, GT, AP } \\
\text { RS, CA } \\
\text { RS, CA, CV, AT, AG, AF, GT } \\
\text { RS, CA, CV, AT, AG, AF, GT } \\
\text { AG, AF } \\
\text { RS, AT, AG, AF, GT, AP } \\
\text { RS, CA, CV, AT, AG, AF, GT } \\
\text { RS, CA, CV, AT, AG, AF, GT, AP, AK } \\
\text { RS, AT, AG, AF, AP } \\
\text { AG } \\
\text { RS, CA, CV, AT, AG } \\
\text { RS, CA, AG }\end{array}$ \\
\hline & & & Odonata & $\begin{array}{l}\text { Aeshnidae } \\
\text { Calopterygidae } \\
\text { Coenagrionidae } \\
\text { Corduliidae } \\
\text { Gomphidae } \\
\text { Libellulidae } \\
\text { Megapodagrionidae }\end{array}$ & $\begin{array}{l}\text { RS, CA, CV, AT, AG, GT, AP } \\
\text { RS, CA, CV, AT, AG, AF, GT, AP, AK } \\
\text { RS, CA, CV, AT, AG, AF, GT, AP, AK } \\
\text { AC, AP } \\
\text { RS, CA, CV, AT, AG, AF, GT, AP, AK } \\
\text { RS, CA, CV, AT, AG, AF, GT, AK } \\
\text { RS, CV, AP }\end{array}$ \\
\hline & & & Plecoptera & $\begin{array}{l}\text { Grypopterygidae } \\
\text { Perlidae }\end{array}$ & $\begin{array}{l}\mathrm{RS}, \mathrm{CA}, \mathrm{CV}, \mathrm{AT}, \mathrm{AG}, \mathrm{GT}, \mathrm{AP}, \mathrm{AK} \\
\mathrm{RS}, \mathrm{CA}, \mathrm{CV}, \mathrm{AT}, \mathrm{AG}, \mathrm{AF}, \mathrm{GT}, \mathrm{AP}\end{array}$ \\
\hline & & & Trichoptera & Glossosomatidae & RS \\
\hline
\end{tabular}

*RS (Sinos), CA (Caraá), CV (Carvalho), AT (Tucanos), AG (Guarda), AF (Funil), GT (Guari-Taimbé), AP (Peão), and AK (Kruze). 
Table 2. Continued...

\begin{tabular}{|c|c|c|c|c|c|}
\hline & & Class & Order & Family & Stream Occurrence* \\
\hline \multirow{12}{*}{ 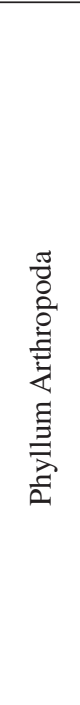 } & \multirow{7}{*}{ 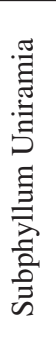 } & \multirow{12}{*}{ Malacostraca } & & Hydrobiosidae & $\mathrm{RS}$ \\
\hline & & & & Hydropsychidae & RS, CA, CV, AG, AF, GT, AP \\
\hline & & & & Leptoceridae & $\mathrm{RS}, \mathrm{CA}, \mathrm{AT}, \mathrm{AG}, \mathrm{GT}$ \\
\hline & & & & Philopotamidae & RS, CA, CV, AT, AG, GT, \\
\hline & & & Lepidoptera & Pyralidae & $\mathrm{RS}, \mathrm{AG}, \mathrm{AF}$ \\
\hline & & & Megaloptera & Corydalidae & $\mathrm{RS}, \mathrm{CA}, \mathrm{CV}, \mathrm{AG}$ \\
\hline & & & Collembola & & $\mathrm{CA}, \mathrm{CV}, \mathrm{AT}, \mathrm{AF}$ \\
\hline & \multirow{5}{*}{ 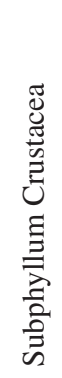 } & & Decapoda & Aeglidae & RS, CA, CV, AT, AG, GT, AP \\
\hline & & & & Palaemonidae & $\mathrm{CA}, \mathrm{CV}, \mathrm{AT}, \mathrm{AG}, \mathrm{AF}, \mathrm{GT}, \mathrm{AP}$ \\
\hline & & & & Trichodactylidae & RS, CA, CV, AT, AG, AF, GT, AP \\
\hline & & & Amphipoda & Dogielinotidae & CA, CV, AT, AF, GT \\
\hline & & & Isopoda & Cymothoidae & $\mathrm{CA}, \mathrm{CV}, \mathrm{AT}, \mathrm{AG}, \mathrm{GT}$ \\
\hline \multirow{9}{*}{ 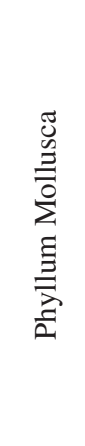 } & & Gastropoda & Mesogastropoda & Ampullaridae & $\mathrm{CA}, \mathrm{AT}, \mathrm{AG}, \mathrm{AF}, \mathrm{GT}$ \\
\hline & & & & Hydrobiidae & $\mathrm{CA}, \mathrm{CV}, \mathrm{AT}, \mathrm{AG}, \mathrm{GT}$ \\
\hline & & \multirow{7}{*}{ Bivalvia } & Basommatophora & Lymnaeidae & AT \\
\hline & & & & Physidae & $\mathrm{AP}, \mathrm{AK}$ \\
\hline & & & & Planorbidae & $\mathrm{AG}, \mathrm{AT}, \mathrm{AK}$ \\
\hline & & & Eulamellibranchia & Sphaeridae & $\mathrm{CV}$ \\
\hline & & & Veneroida & Corbiculidae & CA, CV, AT, AG, GT \\
\hline & & & Unionoida & Hyriidae & $\mathrm{CA}, \mathrm{CV}, \mathrm{AT}, \mathrm{AF}, \mathrm{GT}$ \\
\hline & & & & Mycetopodidae & $\mathrm{CA}$ \\
\hline \multirow{2}{*}{ 声䄈 } & & Hirudinea & & & RS, AT, AF, GT, AP, AK \\
\hline & & Oligochaeta & & & RS, CA, CV, AT, AG, AF, GT, AP, AK \\
\hline
\end{tabular}

*RS (Sinos), CA (Caraá), CV (Carvalho), AT (Tucanos), AG (Guarda), AF (Funil), GT (Guari-Taimbé), AP (Peão), and AK (Kruze).

Table 3. Water quality of the studied streams of the Sinos river basin through the family-level biotic index (FBI) and Biological Monitoring Working Party (BMWP).

\begin{tabular}{|c|c|c|c|c|c|c|c|c|}
\hline \multirow{2}{*}{ Stream } & \multicolumn{4}{|c|}{ FBI } & \multicolumn{4}{|c|}{ BMWP } \\
\hline & Winter & Class & Summer & Class & Winter & Class & Summer & Class \\
\hline Sinos & 4.135 & II & 4.4 & III & 173 & I & 176 & $\mathrm{I}$ \\
\hline Caraá & 4.366 & III & 4.397 & III & 216 & I & 193 & I \\
\hline Carvalho & 3.568 & I & 4.372 & III & 160 & I & 157 & I \\
\hline Tucanos & 4.936 & III & 5.009 & III & 178 & I & 149 & I \\
\hline Guarda & 4.625 & III & 5.073 & IV & 163 & I & 181 & I \\
\hline Funil & 6.325 & IV & 6.11 & V & 133 & I & 151 & I \\
\hline Guari-Taimbé & 4.562 & III & 5.055 & III & 153 & I & 137 & I \\
\hline Peão & 6.805 & VI & 7.18 & VI & 85 & II & 87 & II \\
\hline Kruze & 7.257 & VI & 6.847 & VI & 58 & IV & 56 & IV \\
\hline
\end{tabular}


Table 4. Water quality and Monalisa index of streams of Sinos River basin. $1=$ upper reach; $2=$ middle reach; $3=$ lower reach.

\begin{tabular}{|c|c|c|c|c|c|c|c|c|c|c|c|}
\hline \multirow{2}{*}{ Reach } & \multirow{2}{*}{ Region } & \multirow{2}{*}{$\begin{array}{c}\text { Stream } \\
\text { reach }\end{array}$} & \multicolumn{4}{|c|}{ FBI } & \multicolumn{4}{|c|}{ BMWP } & \multirow{2}{*}{$\begin{array}{c}\text { Monalisa } \\
\text { index }\end{array}$} \\
\hline & & & Winter & Class & Summer & Class & Winter & Class & Summer & Class & \\
\hline \multirow{9}{*}{ Upper } & Upper & Sinos 1 & 4.917 & III & 5.134 & IV & 90 & I & 60 & III & 0 \\
\hline & Upper & Caraá 1 & 3.833 & II & 3.043 & I & 83 & II & 102 & I & 3.5 \\
\hline & Upper & Carvalho 1 & 3.660 & II & 4.596 & III & 91 & I & 102 & I & 10.5 \\
\hline & Middle & Tucanos 1 & 5.418 & IV & 5.524 & IV & 102 & I & 94 & I & 0 \\
\hline & Middle & Guarda 1 & 4.120 & II & 5.032 & IV & 95 & I & 131 & I & 3.5 \\
\hline & Middle & Funil 1 & 3.626 & I & 5.330 & IV & 108 & I & 116 & I & 8 \\
\hline & Lower & Guari-Taimbé 1 & 4.860 & III & 4.787 & III & 69 & III & 54 & IV & 0 \\
\hline & Lower & Peão 1 & 4.704 & III & 5.512 & IV & 69 & III & 77 & II & 9.5 \\
\hline & Lower & Kruze 1 & 5.562 & IV & 5.017 & IV & 52 & IV & 50 & IV & 9.5 \\
\hline \multirow{9}{*}{ Middle } & Upper & Sinos 2 & 4.395 & III & 4.581 & III & 82 & II & 104 & I & 9 \\
\hline & Upper & Caraá 2 & 4.123 & II & 4.909 & III & 146 & I & 115 & I & 25.5 \\
\hline & Upper & Carvalho 2 & 3.814 & II & 4.221 & II & 103 & I & 87 & II & 30 \\
\hline & Middle & Tucanos 2 & 4.321 & III & 4.200 & II & 122 & I & 55 & IV & 7 \\
\hline & Middle & Guarda 2 & 4.858 & III & 5.036 & IV & 77 & II & 112 & I & 7 \\
\hline & Middle & Funil 2 & 6.272 & $\mathrm{~V}$ & 5.166 & IV & 75 & I & 81 & II & 10.5 \\
\hline & Lower & Guari-Taimbé 2 & 4.496 & III & 5.720 & IV & 131 & I & 77 & II & 10.5 \\
\hline & Lower & Peão 2 & 7.974 & VII & 8.000 & VII & 8 & VII & 2 & VII & 11 \\
\hline & Lower & Kruze 2 & 7.546 & VII & 7.944 & VII & 29 & $\mathrm{VI}$ & 8 & VII & 13.5 \\
\hline \multirow{9}{*}{ Lower } & Upper & Sinos 3 & 3.608 & $\mathrm{I}$ & 3.507 & I & 129 & I & 143 & $\mathrm{I}$ & 10.5 \\
\hline & Upper & Caraá 3 & 4.898 & III & 5.279 & IV & 140 & I & 107 & I & 11.5 \\
\hline & Upper & Carvalho 3 & 3.302 & I & 4.327 & III & 133 & I & 119 & I & 19.5 \\
\hline & Middle & Tucanos 3 & 5.126 & IV & 5.316 & IV & 84 & II & 71 & III & 6 \\
\hline & Middle & Guarda 3 & 4.972 & III & 5.148 & IV & 112 & I & 48 & IV & 5.5 \\
\hline & Middle & Funil 3 & 8.000 & VII & 8.000 & VII & 2 & VII & 2 & VII & 29 \\
\hline & Lower & Guari-Taimbé 3 & 4.365 & III & 4.626 & III & 104 & $\mathrm{I}$ & 97 & I & 19 \\
\hline & Lower & Peão 3 & 7.880 & VII & 7.976 & VII & 18 & VI & 12 & VII & 22 \\
\hline & Lower & Kruze 3 & 8.014 & VII & 7.464 & VII & 3 & VII & 11 & VII & 33 \\
\hline
\end{tabular}

throughout the studied period (winter, $\mathrm{r}=0.492, \mathrm{p}=0.009$; and summer, $\mathrm{r}=0.381, \mathrm{p}=0.050)$, the BMWP index was not correlated with the Monalisa index ( $\mathrm{p}>0.05)$.

\section{Discussion}

The Sinos River basin presents different levels of degradation and human occupation along its longitudinal gradient. According to FEPAM (2008), the upper region of the basin is an area of low population density, with few rural settlements whose agriculture is diversified and in which cattle raising is little developed. In the middle and lower regions of the basin, the population density is higher, presenting great industrial complexes. The biotic indices based on the macroinvertebrate community revealed that the water quality varied between the regions of the Sinos River basin. The water quality of the streams decreased from the upper region towards the lower region of the basin, as well as the incidence and increase of certain types of environmental impact according to the Monalisa index. Chironomidae was the dominant macroinvertebrate family in the streams of the lower region. This family presents, generally, a higher resistance to pollution than the other macroinvertebrate families, especially due to its ability to support low rates of oxygen (Merrit and Cummins, 1996; Suriano and Fonseca-Gessner, 2004).

Despite the invariance of the biotic indices between the stream reaches, strong evidence that the water quality of the upper reaches was better than the other reaches was found. Generally, the upper reaches of the streams presented good water quality, except for in one stream of the lower region of the basin. These results reinforce the importance of such upper reaches as habitat for conservation, even in the most compromised regions (lower region). This finding is important to guide policies regarding the conservation and restoration of water resources of the Sinos River basin.

Many researchers have found a seasonal variation of the biotic indices in European and North American countries (Murphy, 1978). With regard to southern Brazil, such variation was not completely studied. Our study has revealed that the indices employed did not change over the studied period. This result demonstrates that the water quality may be analysed in both studied seasons (summer and winter) using the FBI and the BMWP indices; however, a greater sensibility was evidenced in the summer, when the water flow is considerably lower. The FBI index identified that 
some streams of the upper and middle regions presented a reduction in the water quality in the summer.

The stream reaches that presented the worst levels of environmental quality (Monalisa index) also presented the worst level of water quality. However, only the FBI was correlated with the Monalisa index over the studied period. Therefore, the FBI was more consistent with the Monalisa index than the BMWP, reflecting a significant relationship between the incidence and the frequency of the environmental impact with variation of the water quality in the Sinos River basin. The Monalisa index showed that the three regions of the basin presented a range of changes - from the inexistence of the anthropic impacts to different levels of environmental degradation - and that the main difference in the environmental quality of the basin was found between the reaches of the streams and not between the regions of the basin. On the other hand, the studied biotic indices evidenced that the water quality varied mainly between the regions of the basin. Thus, the biotic indices used were efficient to detect the different levels of water quality in the streams of the regions of the basin.

Our results show that the streams of the Sinos River basin presented, generally, good water quality throughout the studied period. However, the streams of the upper region presented better water quality than the streams of the middle and lower regions. On the other hand, the upper reaches of the tributaries of the Sinos River, even those located in more degraded regions of the basin, presented better water quality than the middle and lower reaches. Such information corroborated with the results of environmental quality generated by the Monalisa index, mainly in relation to the family-level biotic index. The analysis of the results allows us to conclude that the biotic indices used reflected the changes related to the water quality along the longitudinal gradient of the basin. Thus, aquatic macroinvertebrates were important bioindicators of the water and environmental quality of the streams of the Sinos River basin.

Acknowledgements - This research was supported by funds from PETROBRÁS AMBIENTAL (Dourado project). Leonardo Maltchik holds a Brazilian Research Council - CNPq Research Productivity grant.

\section{References}

ALLAN, JD., ERICKSON, DL. and FAY, J., 1997. The influence of catchment land use on stream integrity across multiple spatial scales. Freshwater Biology, vol. 37, no. 1, p. 149-161.

ARIAS, ARL., BUSS, DF., ALBUQUERQUE, C., INÁCIO, AF., FREIRE, MM., EGLER, M., MUGNAI, R. and BAPTISTA, DF., 2007. Utilização de bioindicadores na avaliação de impacto e no monitoramento da contaminação de rios e córregos por agrotóxicos. Ciência e saúde coletiva, vol. 12, no. 1, p. 61-72.

ARMITAGE, PD., MOSS, D., WRIGHT, JF. and FURSE, MT., 1983. The performance of anew biological water quality score system based on macroinvertebrates over a wide range of unpolluted running-water sites. Water Research, vol. 17, no. 3, p. 333-347.
BARBOUR, MT., GERRITSEN, J., SNYDER, BD. and STRIBLING, JB., 1999. Rapid Bioassessment Protocols for Use in Streams and Wadeable Rivers: Periphyton, Benthic Macroinvertebrates and Fish. Washington: U.S. Environmental Protection Agency. EPA 841-B-99-002.

CALLISTO, M., MORETTI, M. and GOULART, MDC., 2001. Macroinvertebrados bentônicos como ferramenta para avaliar a saúde de riachos. Revista Brasileira de Recursos Hídricos, vol. 6 , no. 1, p. 71-82.

Comitesinos, 2000. Enquadramento das águas da Bacia Hidrográfica do Rio dos Sinos. São Leopoldo: Impresul. 16 p.

Comitesinos/Unisinos, 2006. Identificação das situações de impacto da Bacia Hidrográfica do Rio dos Sinos - retirada e devolução de água (Projeto MONALISA). São Leopoldo: COMITESINOS/ UNISINOS

COSTA, C., IDE, S. and SIMINKA, CE., 2006. Insetos Imaturos. Metamorfose e Identificação. Ribeirão Preto: Holos Editora

CZERNIAWSKA-KUSZA, I., 2005. Comparing modified biological monitoring working party score system and several biological indices based on macroinvertebrates for water-quality assessment. Limnologica, vol. 35, no. 3, p. 169-176.

Departamento de Recursos Hídricos - DRH and Secretaria Estadual de Meio Ambiente - SEMA, 2008. Relatório anual sobre a situação dos Recursos Hídricos no Estado do Rio Grande do Sul. Porto Alegre: DRH/SEMA.

DURAN, M., 2006. Monitoring water quality using benthic macroinvertebrates and physicochemical parameters of Behzat stream in Turkey. Polish Journal of Environmental studies, vol. 15, no. 5, p. 709-717.

FEPAM, 2008. Qualidade ambiental da região hidrográfica do Guaíba. Available from: <http://www.fepam.rs.gov.br/qualidade/ qualidade_sinos/sinos.asp $>$. Access in: Nov. 2008.

FERNÁNDEZ, HR. and DOMINGUEZ, E., 2001. Guía para la determinación de los artrópodos bentónicos sudamericanos. Tucumán: Universidad Nacional de Tucumán.

GALDEAN, N., CALLISTO, M. and BARBOSA, FAR., 2000. Lotic ecosystems of Serra do Cipó, southeast Brazil. Water quality and a tentative classification based on the benthic macroinvertebrate community. Aquatic Ecosystem Health \& Management, vol. 3, no. 4 , p. 545-552.

GOLDSTEIN, RM., CARLISLE, DM., MEADOR, MR. and SHORT, TM., 2007. Can basin land use effects on physical characteristics of streams be determined broad geographic scales? Environmental Monitoring Assessment, vol. 130, no. 1-3, p. 495-510.

HARDING, JS., BENFIELD, EF., BOLSTAD, PV., HELFMAN, GS. and JONES III, EBD., 1998. Stream biodiversity: the ghost of land use past. Ecology, vol. 95, no. 25, p. 14843-14847.

HILSENHOFF, WL., 1987. An improved biotic index of organic stream pollution. Great Lakes Entomology, vol. 20, no. 1, p. 31-39.

HUNTSAKER, CT. and LEVINE, DA., 1995. Hierarchical approaches to the study of water quality in rivers: spatial scale and terrestrial processes are important in developing models to translate research results to managemet practices. BioScience, vol. 45 , no. 3 , p. 195-203. 
JUNQUEIRA, MV. and CAMPOS, SCM., 1998. Adaptation of the BMWP for water quality evaluation to Rio das Velhas watershed (Minas Gerais, Brazil). Acta Limnologica Brasiliensia, vol. 10, no. 2, p. 125-135.

KASANGAKI, A., CHAPMAN, LJ. and BALIRWA, J., 2008. Land use and the ecology of benthic macroinvertebrate assemblages of high-altitude rainforest streams in Uganda. Freshwater Biology, vol. 53, no. 4, p. 681-697.

KOLKWITZ, R. and MARSSON, M., 1908. Ökologie der pflanzlichen Saprobien. Berichte der Deutsche Botanischen Gesellschaft, vol. 26, no. 2, p. 505-519.

LOPRETTO, EC. and TELL, G., 1995. Ecosistemas de Aguas Continentales. Metodologías para su estudio. La Prata: Ediciones Sur.

MARQUES, MM. and BARBOSA, FAR., 2001. Na fauna do fundo, o retrato da degradação. Ciência Hoje, vol. 30, no. 175, p. 72-75.

MATTHEWS, RA., BUIKEMA, AL. and CAIRNS Jr., J., 1982. Biological monitoring part IIA: Receiving system functional methods relationships, and indices. Water Research, vol. 16, p. $129-139$

MERRITT, RW. and CUMMINS, KW., 1996. An Introduction to the Aquatic Insects of North America. Iowa: Kendall/Hunt Publishing Company.

METCALFE, JL., 1989. Biological water quality assessment of running waters based on macroinvertebrate communities: history and present status in Europa. Environmental Pollution, vol. 60, p. 101-139.

MONTEIRO, TR., OLIVEIRA, LG. and GODOY, BS., 2008. Biomonitoramento da qualidade de água utilizando macroinvertebrados bentônicos: adaptação do índice biótico BMWP à Bacia do Rio Meia Ponte-GO. Oecologia Brasiliensis, vol. 12 , no. 3 , p. 553-563.
MORENO, P. and CALLISTO, M., 2004. Bioindicadores de qualidade de água ao longo da bacia do Rio das Velhas (MG). In FERRACINI, VL., QUEIROZ, SCN. and SILVEIRA, MP. (Eds.). Bioindicadores de qualidade da água. Jaguariuna: Embrapa. p. 95-116.

MURPHY, PM., 1978. The temporal variability in biotic indices. Environmental Pollution, vol. 17, no. 3, p. 227-236.

RESH, VH., 2007. Multinational, freshwater biomonitoring programs in the developing world: Lessons learned from African and Southeast Asian river surveys. Environmental Management, vol. 39 , no. 5 , p. 737-748.

STRIEDER, MN., RONCHI, LH., NEISS, UG. and OLIVEIRA, MZ., 2003. Avaliação dos efeitos de fontes de poluição pontual sobre macroinvertebrados bentônicos no arroio Peão, RS. In RONCHI, LH. and COELHO, OGW. (Eds.). Tecnologia, diagnóstico e planejamento ambiental. São Leopoldo: Unisinos. p. 61-86.

STRIEDER, MN., SCHERER, RT. and VIEGAS, G., 2006a. Biomonitoramento da qualidade das águas em arroios na bacia hidrográfica do Rio dos Sinos, Rio Grande do Sul, Brasil. Unirevista, vol. 1, no. 1, p. 47-56.

STRIEDER, MN., RONCHI, LH., STENERT, C., SCHERER, RT. and NEISS, UG., 2006b. Medidas biológicas e índices de qualidade da água em uma microbacia com poluição urbana e de curtumes no Sul do Brasil. Acta Biologica Leopoldensia, vol. 28 , no. 1 , p. $17-24$

SURIANO, MT. and FONSECA-GESSNER, AA., 2004. Chironomidae (Diptera) larvae in streams of Parque Estadual de Campos do Jordão, São Paulo state, Brazil. Acta Limnologica Brasiliensia, vol. 16, no. 2, p. 129-136.

Systat, 2007. Systat Software. California: Richmond.

WHITFIELD, J., 2001. Vital Signs. Nature, vol. 411, no. 28, p. $989-900$. 